\title{
Conflicting Traditions: The Interpretation of Daniel's Four Kingdoms in the Ethiopic Commentary (Tergwāāmē) Tradition
}

\author{
James R. Hamrick
}

In Daniel we encounter the scripturalization of the four kingdoms motif. The work itself presents the division of history into four temporal kingdoms (and one eternal one) as a sacred reality, embedding the motif within inspired dreams and visions. The acceptance of Daniel as canonical by the church and synagogue has ensured that two millennia of biblical interpreters have used the motif in their framing of world history and their understanding of the future. In this contribution I examine the reception of Daniel's four kingdoms in one area typically overlooked in the study of biblical reception history: medieval Africa. The tergwāmē, or Ge'ez (classical Ethiopic) commentaries to Daniel, continue the hermeneutical work already begun within Daniel itself by deciphering the symbols left untouched by the dream-interpreter Daniel and the interpreting angel. These commentaries do this in different ways, inheriting and developing various interpretive traditions that sometimes offer conflicting understandings of the identities of the body parts of the statue in Nebuchadnezzar's dream and the four animals in Daniel's. Within one of the commentaries these different traditions are identified, explained, allowed to coexist, and ultimately reconciled with each other. In bringing disparate traditions together the terg'āmē provide a good window into some of the issues in the broader reception history of Daniel's four kingdoms and offer a glimpse into the Ethiopian commentary tradition.

Tergwāmē, a Ge'ez word meaning "interpretation" or "translation," refers to the extensive corpora of Ge'ez commentary materials, primarily on biblical and liturgical texts. This is to be distinguished from the andemta, which 
are commentaries written in the Amharic language. ${ }^{1}$ While tergwāmē manuscripts are extant for the majority of Ethiopian biblical texts, they remain largely unedited and untranslated in Western scholarship. Exceptions are Garcia's edition of Ethiopian commentaries to Micah and Cowley's English translation of the Tergwāmē to Revelation. ${ }^{2}$ This scholarly neglect is unfortunate, as these commentaries provide us with interesting insights into the textual history and reception of biblical texts. They also preserve earlier exegetical traditions rooted in Greek and Syriac biblical interpretation. For example, one of the tergwāmē to Daniel preserves extensive citations from Hippolytus of Rome's third-century CE commentary to Daniel. Some of the terg $^{\mathrm{w}} \overline{\mathrm{a}} \mathrm{me}$ are translations of Arabic sources, providing us with witnesses to Arabic Christian interpretation of scripture as it was received in an Ethiopian context. ${ }^{3}$ There are also indigenous Ethiopian commentaries, which are significant sources in understanding the reception of the Bible within an African context, something that is invaluable as Western scholarship attempts to move away from its preoccupation with Greek and Latin sources in the study of Christian history.

In addition to their value as sources for exegetical traditions, the lemma in these commentaries are also useful witnesses in the production of critical editions of Ge'ez scriptural texts and the study of their textual history in the Ethiopian tradition. For example, Löfgren and Fuhs both made use of the lemma from the commentary materials in Österreichische Nationalbibliothek,

1 The primary authority for these materials is still Roger W. Cowley, Ethiopian Biblical Interpretation: A Study in Exegetical Tradition and Hermeneutics (Cambridge: Cambridge University Press, 1988). See also Keon-Sang An, An Ethiopian Reading of the Bible: Biblical Interpretation of the Ethiopian Orthodox Tewahido Church (Eugene, OR: Pickwick, 2015).

2 Miguel Angel Garcia, Ethiopian Biblical Commentaries on the Prophet Micah (Wiesbaden: Harrassowitz, 1999); Roger W. Cowley, The Traditional Interpretation of the Apocalypse of St. John in the Ethiopian Orthodox Church (Cambridge: Cambridge University Press, 1983). See also Kirsten Stoffregen-Pedersen, Traditional Ethiopian Exegesis of the Book of Psalms (Wiesbaden: Harrassowitz, 1995); and Weldetensae Andeberhan, Commentari Etiopici sul Libro del Profeta Osea (Wiesbaden: Harrassowitz, 1994).

3 Roger Cowley, Ethiopian Biblical Interpretation; "A Ge'ez Document Reporting Controversy concerning the Bible Commentaries of Ibn at-Tayib," RSE 30 (1987): 5-13; Aaron Michael Butts, "Embellished with Gold: The Ethiopic Reception of Syriac Biblical Exegesis," OrChr 97 (2013/2014): 137-59. Both Cowley and Butts note especially the influence of the Arabic commentator ibn al-Tayyib on the Ethiopian (Ge'ez and Amharic) commentary tradition. Unfortunately, ibn al-Tayyib's commentary on the Bible, The Paradise of Christianity, remains almost entirely unedited, the exception being J. C. J. Sanders, Commentaire sur la Genèse, csco 274-75 (Leuven: Peeters, 1967). The editing and translation of Arabic and Ethiopic commentary materials remains a major desideratum in the growing field of biblical reception history. 
Cod. aethiop. 16 (Wien 16) in their editions of Daniel, Hosea, and Micah. ${ }^{4}$ In my own work on the terg ${ }^{w}$ āmē to Daniel, I have found several significant examples of the lemma from the commentary influencing Ge'ez Daniel manuscripts, and vice versa. As an example of the commentary lemma influencing Daniel manuscripts, see my note on Daniel 11 below, or Bibliothèque nationale de France, Éthiopien d'Abbadie 35, a Ge'ez Daniel manuscript that includes interlinear textual additions drawn from the lemma of one of the tergwāmè. As an example of Daniel manuscripts influencing the commentary, some tergwāmē manuscripts supplement their abbreviated lemma for the Song of the Three in Daniel 3 by drawing on the mainstream Ge'ez version.

Daniel is one of the most attested works among tergwāmē manuscripts, with at least three distinct commentaries at least fragmentarily represented, and several different recensions. The most comprehensive work, which I label TDan1, offers a complete Ge'ez translation and extensive commentary to the entire book of Daniel, including Bel and the Dragon and the "additions" to Daniel 3, but sans Susanna. The earliest, fullest recension of this tergwāmē (TDania) is attested in five manuscripts, with the earliest witness from the latefifteenth or early-sixteenth centuries. ${ }^{5}$

These terg'āmē manuscripts present the text of Daniel in sections of varying length, which are then followed by commentary sections, also of varying length. The Ge'ez translation of Daniel in this recension is different from the translation of Daniel otherwise attested in the Ge'ez manuscript tradition. The

4 Oscar Löfgren, Die äthiopische Übersetzung des Propheten Daniel (Paris: Geuthner, 1927); Hans Ferdinand Fuhs, Die äthiopische Übersetzung des Propheten Micha (Bonn: Hanstein, 1968); Hans Ferdinand Fuhs, Die äthiopische Übersetzung des Propheten Hosea (Bonn: Hanstein, 1971).

5 The manuscripts are Gunda Gundē 84 (GG84), early-sixteenth century; Gunda Gundē 131 (GG131), late-fifteenth/early-sixteenth century; UNESCO 10.47/EMDA 392 seventeenth century; EMML 6269/EMIP 1074, early-eighteenth century; and British Library Endangered Archives Programme 336/2/3 (EAP 336/2/3), twentieth century. Images of the Gunda Gundē and EMML manuscripts are freely available through the Hill Museum \& Manuscript Library's online reading room (https://www.vhmml.org/). EMML 6269 is also available on microfilm at the National Archives and Library of Ethiopia in Addis Ababa. I obtained the color image set EMIP 1074 from Professor Steve Delamarter. One can order UNEsCo 10.47 (scanned microfilm)/EMDA 392 (color images) from the Hill Museum \& Manuscript Library. Images of EAP $336 / 2 / 3$ are only available for on-site viewing on the computer terminals in the British Library reading rooms. Catalogue entries have yet to appear in print for any of these manuscripts. Ted Erho is currently cataloguing the Gunda Gundē collection, and GG84 and GG131 are recorded in the handlist published by Antonio Mordini, "Il convento di Gunde Gundiè," RSE 12 (1953): 48. UNESCO 10.47 is recorded in Catalogue of Manuscripts Microfilmed by the UNESCO Mobile Microfilm Unit in Addis Ababa and Gojjam Province (Addis Ababa: Ministry of Education and Fine Arts, Department of Fine Arts and Culture, 1970). I am grateful to Ted Erho for initially drawing my attention to many of these manuscripts. 
latter, "received" version, was originally translated from a Greek (Theodotionic) Vorlage in the late-antique Aksumite period. The version in this tergwāmē is, however, a distinct translation based ultimately on the Syriac Peshitta, although likely translated into Ge'ez through an Arabic intermediary (Syriac > Arabic > Ge'ez). ${ }^{6}$ The date, author, and origins of the tergwāmē are still unknown, but it was likely translated into Ge'ez from an Arabic source in the fourteenth century or earlier. The text of Daniel contains expansions that begin to appear in Peshitta manuscripts in the ninth and tenth centuries, providing us with a terminus post quem for the work as it now stands. As we will see later, the commentary incorporates much earlier traditions, citing authors such as Hippolytus of Rome, Theodoret of Cyrus, and Gregory Nazianzus.

Wien $16^{7}$ preserves a second version of this work (TDanı), which may actually be an independent translation of the presumed Arabic version of the commentary. Rather than the Peshitta-based version of Daniel in TDanı, this recension uses the mainstream Ge'ez Daniel translation, while integrating occasional readings from the Peshitta-based version. The tergwāmē sections differ occasionally in content from TDanı, but primarily differ in vocabulary and syntax. Bibliothèque nationale de France, Éthiopien d'Abbadie 157 (seventeenth century; TDanic) offers a radically abbreviated reworking of TDanıa. ${ }^{8}$

In addition to these recensions, two portions of the commentary were received in the Ethiopian liturgical and scriptural traditions. A portion of the commentary to Daniel 7 is one of several terg'āmē excerpts that appear in the Gebra Hemāmāt, the lectionary for Passion Week. ${ }^{9}$ The reading from Daniel conforms to the mainstream Ge'ez Daniel tradition, and the commentary has been lightly reworked. Part of the tergwāmè's translation of Daniel 11 has been incorporated in various ways into some Ge'ez Daniel manuscripts as a way of correcting the clearly defective form of the chapter that appears in our earliest

6 Oscar Löfgren's Die äthiopische Übersetzung des Propheten Daniel (Paris: Geuthner, 1927) is still our most current edition of Ge'ez Daniel. Löfgren collated the lemma from the Daniel terg'āmē preserved in Wien 16 (the recension I label TDanıb), offering some short remarks on the commentary itself, including an argument based on transliterated names that the work is a translation from Arabic (XXXVII-XXXVIII).

7 Nr. I in Nikolaus Rhodokanakis, Die äthiopischen Handschriften der K.K. Hofbibliothek zu Wien (Wien: Hölder, 19o6), 3-15. While Rhodokanakis dates the manuscript to the sixteenth century (Die äthiopischen Handschriften, 15), Löfgren assigns it to the seventeenth century (Die äthiopische Übersetzung des Propheten Daniel, Xxxvi), and Ted Erho to the lateseventeenth or eighteenth centuries (personal correspondence).

8 M. Chaîne, Catalogue des Manuscrits Éthiopiens de la Collection Antoine D’Abbadie (Paris: Imprimerie Nationale, 1912), 95 .

9 This fragment appears in our earliest Gebra Hemāmāt manuscripts and continues to appear in modern printed editions of the work. 
extant witnesses to the book. ${ }^{10}$ This commentary thus has a rich reception history in the Ethiopic tradition. This history begins with its translation(s) into Ge'ez, where Ethiopian scribes then reworked it in different ways. Its influence spread beyond commentary manuscripts, as excerpts found their way into important liturgical works and biblical manuscripts.

A second tergwāmē (TDan2), likely an indigenous Ethiopian composition, is preserved in varying forms in British Library, Orient. 743 (BL743; TDan2a), Gunda Gundē 112 (GG112; TDan2b), and Gunda Gundē 111 (GG111; TDan2c). A third tergwāmē fragment to Daniel 2 and 7 is also found in BL743 and EMML 8260 (TDan3). BL743 preserves a fourth fragment with commentary to Dan 11:35 and the entirety of Daniel 12 (TDan4). A fifth tergwāmē is attested by EMML 8971 (sixteenth century; TDan5), which does share materials in common with TDanı but diverges enough that I classify it as a separate work. I am currently producing a critical edition and English translation of all of the Daniel tergwāmē materials as part of my doctoral dissertation at the Ludwig-Maximilians-Universität München, "A Critical Edition and Translation of the Ethiopic Commentaries to the Book of Daniel."

\section{Continuing the Work of the Interpreting Angel}

We will see that these various commentaries offer differing interpretations of the visions in Daniel 2 and 7, but they do share a basic approach. We can best understand the tergwāmē to Daniel, especially the sections dealing with dreams and visions, as a continuation of the interpretive work of Daniel and the interpreting angel. The characters in Daniel receive various dreams and visions, which they experience as something with opaque meaning and significance, something requiring interpretation and explanation. They find themselves unable to unlock these troubling and confusing phenomena and, therefore, seek the help of others. Nebuchadnezzar summons a series of specialists, while

10 This is based on an analysis of Daniel 11 in images from fifty-two Ge'ez Daniel manuscripts, most of which I accessed while the recipient of a Heckman Stipend at the Hill Museum \& Manuscript Library in Collegeville, Minnesota. I have identified six major forms of this chapter, with three of these forms containing a supplement borrowed from TDania. The manuscripts with this supplement are: Bodleian Library, Ms Bruce 74; Bibliothèque nationale de France Éthiopien 5o; EMDA 249; UNESCO 10.4; UNESCO 10.43; EMML 819; EMML 6252; EMML 8433; EMML 9045. Löfgren noted the existence of this supplement in the first two manuscripts (his $\mathrm{O}$ and $\mathrm{P}$ respectively). However, as he was only aware of TDanıb in Wien 16, which contains a different version of Daniel, he was not able to determine that the supplement came from a Daniel terg'̄āmē (Löfgren, Die äthiopische Übersetzung des Propheten Daniel, XXXIV-XXXvi). 
Daniel asks a figure within his dream-vision, a so-called interpreting angel. In all cases help is (eventually) found, and the confused recipients of dreams and visions receive an interpretation. The interpretation, however, never fully exhausts the symbolic content of the experiences. Daniel and the interpreting angel provide the characters and subsequent readers of the text with only an entryway, foothold, orientation, or key for interpreting the dreams and visions. The interpretations reveal that the dreams and visions of Daniel 2 and 7 are about world history, a series of kingdoms and kings, and their eventual end. The different elements are symbols that represent historical people, institutions, and events. The head of gold is Nebuchadnezzar. The silver breasts and arms are the kingdom that will follow Nebuchadnezzar, with the silver indicating its inferiority to Nebuchadnezzar. The four animals are four kings who will arise out of the earth. The little horn that supplants three horns is a blasphemous king who will put down three kings.

Such interpretations offer a basic orientation that leaves much unexplained. Which kingdoms and kings are these? What does it mean for the lion-like animal to have its wings torn off, or be given a human heart? Who or what is the stone cut without hands? Many elements are ignored by the interpreter within the narrative, and even those elements that are addressed retain an element of mystery. As Brennan Breed expresses it, "the dream retains a surplus of uninterpreted data and so retains a certain mysteriousness that the further interpretation will only partially dispel. The reader is responsible for deducing the meaningfulness of these details."11

The interpretive burden laid on readers was not always an easy one. The earliest interpreters of Daniel's dreams and visions already differed from each other in their attempts to decipher this "uninterpreted data." An ongoing increase in historical and cultural distance and new religious and political developments resulted in a further stretching of the already zehrdehnte Kommunikationssituation, intensifying the interpretive burden. This burden, however, was also an opportunity. By refusing to include exhaustive interpretations of visionary experiences in the text of Daniel itself, the Danielic scribes helped ensure the work's enduring quality, as the "surplus of uninterpreted data" could accommodate new theological, political, and historical developments. Daniel and the interpreting angel left room in the dreams and visions for christs and antichrists, Romans and Arabs.

Textual commentaries attempt to ease this interpretive burden and exploit this interpretive opportunity. They step into the partially undeciphered

11 Carol A. Newsom with Brennan W. Breed, Daniel: A Commentary, отL (Louisville: Westminster John Knox, 2014), 237. 
symbolic world of Danielic dreams and visions, and continue the interpretive work that Daniel and the interpreting angel had left undone. In doing this work the terg'āmē take their lead from the interpretations already offered in Daniel. We can illustrate this with a sample from TDanza:

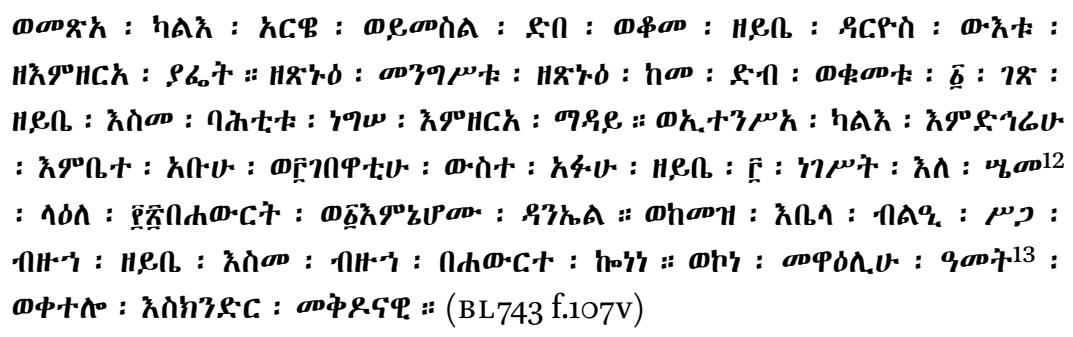

And a second animal came, and it resembled a bear. And it stood. Darius, who was from the seed of Japheth, whose kingdom was strong like a bear is strong. And its position was on one side. He alone reigned from the seed of Madai. Another from the house of his father did not arise after him. And its three rib bones were in its mouth. Three kings whom he appointed over 120 regions, and one of them was Daniel. And likewise I told it, "eat much flesh." He ruled many regions. And his time was [ ] years. ${ }^{14}$ And Alexander the Macedonian killed him.

According to the interpreting figure in the Masoretic, Peshitta, and Ge'ez versions of Daniel 7:17, each of the four animals represents a king who will arise. This tergwāmē identifies the king represented by the bear-like figure: it is Darius the Mede, who is introduced as the successor to Belshazzar in Dan 6:1. His genealogy is keyed to the table of nations in Genesis 10, with the commentator identifying him as a descendant of Japheth's son Madai (Gen 10:2). Daniel does not tell us what it means that the second animal looks like a bear, the significance of it standing on one side while holding three ribs in its mouth, or it being commanded to rise and eat much flesh. Each of these elements is tersely deciphered by the commentator: standing on one side indicates that Darius was the only Median to reign. The three ribs are the three officials (here "kings", n7 $\boldsymbol{\mu}$ i) whom Darius appoints over the one-hundred and twenty satraps (here

\footnotetext{
12 BL 743: hл : ก.ศ\%.

13 GG 112 reads $1,9 m$.

14 Ethiopian scribes sometimes left numeral spaces blank, so that a rubricator could fill them in later. In some cases the rubricator never managed to fill in the blank, leaving the number of years uncertain.
} 


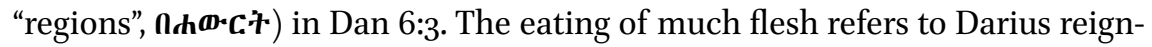
ing over many regions. A historical note about the length of his reign and his death at the hands of Alexander the Macedonian, which confuses Darius the Mede with Darius III, concludes the interpretation. We see in this illustrative example that the terg'āmē to Daniel attempt to decipher the uninterpreted symbols in Daniel's dreams and visions in continuity with the kinds of interpretations already present within the text itself. They draw on information from biblical texts and other historical traditions to help with this task.

Not only is the mode of interpretation inspired by the interpretive activity in Daniel, but the very format of the tergwāmē is patterned after it. Michael Fishbane summarizes the format of the interpretation of dreams and visions in the Hebrew Bible as follows:

A remarkably consistent and common set of structural and terminological components are found with the interpretation of dreams, visions, and (visualized) omens. Most salient is the recurrent citation and atomization of the mantological content in the course of its decoding explication. There is thus, characteristically, first a presentation of the entire content, and then a selected repetition of its lemmata with interpretation. ${ }^{15}$

An example from Daniel is the interpreting angel in Daniel 8, who briefly reiterates the different elements that Daniel saw in the vision, followed by their meaning: "As for the ram that you saw with the two horns, these are the kings of Media and Persia. The male goat is the king of Greece, and the great horn between its eyes is the first king" (8:20-21; NRSV). The tergwāmē, like other examples of Jewish and Christian scriptural commentaries, follow this format in their reiteration of short lines from the text of Daniel, followed by decipherment of their meaning.

There is a hint that the commentator behind TDanı consciously understood and authorized their work as a continuation of the scripture's internal interpretive activity. In the commentary to Daniel 7:16-18, where Daniel approaches a figure in his vision and receives an interpretation, we read:

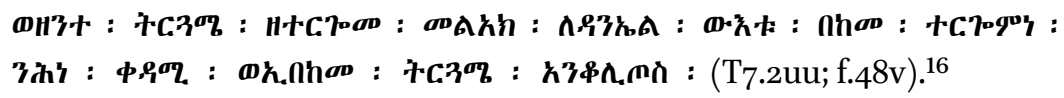

15 Michael Fishbane, Biblical Interpretation in Ancient Israel (Oxford: Clarendon, 1985), 447.

16 The text and versification offered throughout for TDanıa are taken from my in-progress critical edition. As the edition is currently unpublished, I also indicate the folio where each text can be found in EMML 6269, which is currently available online from the Hill 
This interpretation, which the angel gave to Daniel, is just like our interpretation earlier, and not like the interpretation of Hippolytus.

The commentator understands their work, both in form and content, to be in continuity with the work of the interpreting angel in Daniel.

\section{The Fourth Kingdom Is the Greeks}

We move on now to look at some of the specific ways that the four kingdoms/ kings of Daniel 2 and 7 are handled by the tergwāmē, beginning with the interpretation offered by the commentator of TDan1, who offers the sequence (1) the kingdom of Babylon, (2) the kingdom of the Medians, (3) the kingdom of Persia, (4) the kingdom of the Greeks. ${ }^{17}$ This sequence, associated with the Syriac tradition, is also adopted by modern critical scholars. ${ }^{18}$ I mentioned that the text of Daniel in this tergwāmē is ultimately based on the Peshitta to Daniel. Already in early sixth and seventh-century CE Peshitta Daniel manuscripts there are historical rubrics in chapter seven that identify some or all of the four animals with specific kingdoms, and which identify the little horn with Antiochus (Epiphanes added in some Mss). ${ }^{19}$ While Ambrosian Codex, 7 ar has no rubric for the first animal, the sequence of kingdoms given in the manuscripts is otherwise the kingdom of the Babylonians, the kingdom of the Medians, the kingdom of the Persians, and the kingdom of the Greeks. ${ }^{20}$ Some Arabic Daniel manuscripts also include these references. ${ }^{21}$ The text of Daniel in this terg'āmē contains these historical identifications, although they are no

Museum \& Manuscript Library at http://www.vhmml.org. Images of GG84 and GG131 are also available on this website.

17 For a discussion of some historical opinions on the identity of the four kingdoms, see H. H. Rowley, Darius the Mede and the Four World Empires in the Book of Daniel: A Historical Study of Contemporary Theories (Cardiff: University of Wales Press, 1964).

18 Wido van Peursen, "Daniel's Four Kingdoms in the Syriac Tradition," in Tradition and Innovation in Biblical Interpretation: Studies Presented to Professor Eep Talstra on the Occasion of his Sixty-Fifth Birthday, eds. W. Th. van Peursen and J. W. Dyk (Leiden: Brill, 2011), 189-207; Arie van der Kooij, "The Four Kingdoms in Peshitta Daniel 7 in the Light of the Early History of Interpretation," in The Peshitta: Its Use in Literature and Liturgy, ed. Bas Ter Haar Romeny (Leiden: Brill, 2006), 123-129.

19 Konrad D. Jenner, "Syriac Daniel" in The Book of Daniel: Composition and Reception, eds. John J. Collins and Peter W. Flint, VTSup 83, FIOTL 2; (Leiden: Brill, 2001), 2:633-634.

202 sلa 20

21 Such as the ninth-century CE MS Sinai Arabic 1 and the tenth-century Ms Sinai Arabic 513. See Miriam Lindgren Hjälm, Christian Arabic Versions of Daniel: A Comparative Study of Early MSS and Translation Techniques in MSS Sinai Ar. 1 and 2 (Leiden: Brill, 2016). 
longer marked as paratextual elements as they are in Syriac and Arabic witnesses. These references read:

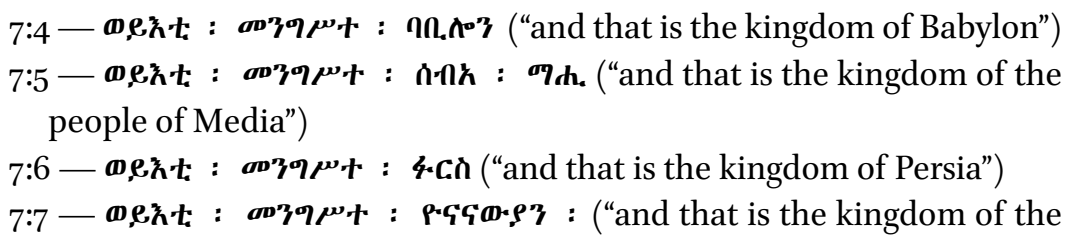
Greeks")

The identification of the little horn as Antiochus also appears:

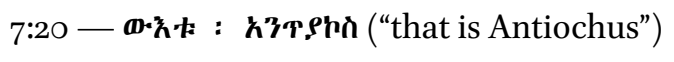

The commentary to Daniel 7 reiterates this sequence, giving explanations for the various details of the animals. ${ }^{22}$ The first animal is Babylon, which, in an allusion to Daniel 2, is the "head" of the kingdoms. It was strong and all people feared it, just like a lion. Its wings like an eagle's symbolize its exaltation and the strength of its command, and that it quickly encircled all the edges of the earth. The plucking off of its wings refers to its destruction and the scattering of its armies, and it standing up indicates the loss of the kingdom and it becoming like all people. Receiving a human heart means that it loses its strong heart and becomes afraid and weak like a feeble human, and is trampled by the poor. The commentary also offers a second interpretation of the humanization of the first animal, suggesting that it refers to what happened to Nebuchadnezzar in Daniel 4 when he dwelt with wild animals.

The second animal, which looks like a bear, is the kingdom of the people of Media. The bear symbolizes this kingdom because it was not as great as Babylon, which preceded it, or Persia, which followed it. It was inferior to these other kingdoms, just as a bear's strength is inferior to a lion, and as it has a timid and weak nature. The bear-like animal stands on one side because Media ruled in one region of this world. The three rib bones in its teeth indicate that it reigned over three kingdoms: Babylon, Media, and Persia. The command to rise and eat much flesh refers to its plunder and consumption of the wealth of the three kingdoms.

The third animal, which looked like a leopard, is the kingdom of Persia, because it was stronger than the Median kingdom, just as the leopard is stronger

22 The interpretation of the four animals is found in $\mathrm{T}_{7.1}(\mathrm{ff} .41 \mathrm{v}-44 \mathrm{v})$. My description of the interpretations is a general paraphrase of the text itself. 
than the bear. The four wings and four heads indicate the expansion of the kingdom and it quickly encircling the entire earth, with it reigning over the four edges of the earth. The animal receiving authority refers to what Isaiah spoke about in his prophecies about Cyrus (Isa 44:28; 45:1).

The fourth animal is the kingdom of Alexander, king of the Greeks, who was exalted above all kingdoms. Its great teeth are its armies, which crush all peoples, plunder their wealth, trample their fields, and reap their fruit and their wine. Its appearance was not like the appearance of the other three animals, but was much more beautiful than them, with the kingdom of Alexander surpassing the kingdoms that were before it in its achievements and in its methods. The things that Alexander did were exceedingly great, and he captured the nations in a short time. The commentator then extols Alexander, who, although his kingdom lasted only twelve years, left an eternal memory through his deeds and his building of cities and fortresses, including the legendary Gates of Alexander. ${ }^{23}$

The ten horns are the ten kings who were appointed over the kingdom of the Greeks. The little horn is Antiochus Epiphanes. The three horns he removes are Seleucus, Ptolemy, and the king of Babylon. He is called the little horn because he was inferior to the others, but then his kingdom became greater than the others. The horn's human-like eye is his cunning, which he used to overcome many and destroy them along with their cities. The mouth that speaks boastfully refers to his conflict with the "learned ones" ( mentary gives to the Maccabees and the faithful Jews in the time of Antiochus Epiphanes.

The commentary to Nebuchadnezzar's dream in Daniel 2 contains this same sequence of kingdoms, but with less elaboration. ${ }^{24}$ The head of gold is the kingdom of Babylon, because its glory was above all the kingdoms. The breast and arms of silver are the kingdom of Media. The belly and hips of bronze are Persia, which shimmered just as pure bronze shimmers. The iron legs, the fourth kingdom, is the kingdom of Alexander the Macedonian, who was strong like iron. The feet that contain clay and iron represent the division of Alexander's kingdom among his four servants at his death, with the iron specifically symbolizing the strong successors of Alexander and the clay symbolizing the weak ones. The descendants of Alexander's successors warred

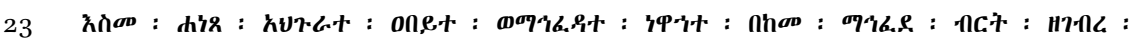

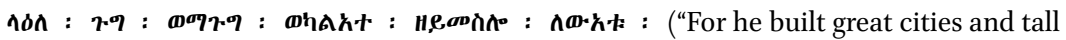
fortresses, like the fortress of brass that he made against Gog and Magog, and the others that resembled it" [T7.1cc; f.44r]). 
with each other and against the Hebrews. They intermarried with each other not in the name of peace, but in deceit. The commentator offers some examples of these conflicts, including Ptolemy marrying his daughter to Alexander the Elder, the son of Antiochus Epiphanes, then taking her and marrying her to Demetrius and killing Alexander.

We see from this brief and selective summary that this tergwāmē inherited a biblical text that contained paratexts that presented a four-kingdom sequence of Babylon, Media, Persia, and Greece. The commentary sections adopt this scheme, with Greece divided into the two stages of Alexander's reign and the reign of his successors. The commentary seeks to fill in this picture by deciphering the surplus symbols in the dream-visions, and by incorporating traditions about Alexander the Great, his successors, and the persecution under Antiochus Epiphanes, which it draws from 1-2 Maccabees (named sources) and possibly from the Alexander Romance. The commentary portrays Alexander and his kingdom very positively, but Media and Alexander's successors negatively. It offers interpretations that are akin to the interpretations one encounters in historical-critical commentaries today, representing an interpretive tradition that has endured through the ancient, medieval, and modern periods of biblical interpretation.

\section{The Fourth Kingdom Is the Romans}

TDanı also includes an alternate interpretation that reflects a widely-attested sequence in the history of interpretation: (1) Babylon, (2) Media and Persia together, (3) Greece, and (4) Rome. In the commentary to Daniel 2:41-43 the commentator introduces a source that will be cited throughout the tergwāmē:

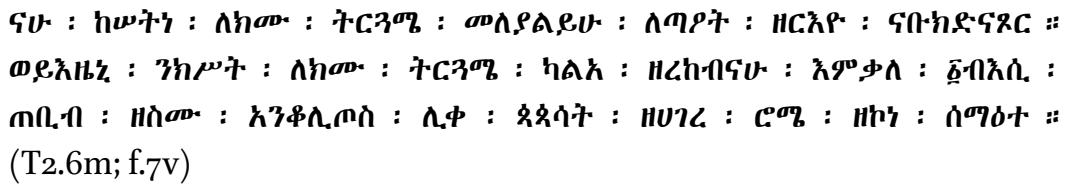

Behold we revealed to you the interpretation of the body parts of the idol that Nebuchadnezzar saw. And now we will reveal to you another interpretation, which we found, from the word of one wise man whose name was Hippolytus, the bishop of the city of Rome, who died a martyr.

This is a reference to Hippolytus of Rome's commentary to Daniel, which is the earliest fully extant Christian commentary to scripture. Written in Greek 
in $204 \mathrm{CE}$, it is extant in Greek and Old Church Slavonic, with fragments in Syriac and Armenian. ${ }^{25}$ In this tergwāmē we now have the first Ge'ez fragments of the work known to Western scholarship. ${ }^{26}$ After this introductory comment the terg'āmē offers Hippolytus's interpretation of the statue: Babylon is the head of gold; Persia and Media are combined as the second kingdom of silver; the third, bronze kingdom is the Greeks; and the iron legs are the Romans. The commentary then attributes to Hippolytus an interpretation of the toes as the Arabs, a point to which I will return below.

Hippolytus is also extensively referenced in the commentary to Daniel 7 . It is noted there that Hippolytus combines the kingdoms of Media and Persia into the bear-like image, identifies the leopard-like animal as the kingdom of the Greeks, the fourth animal as Rome, and the little horn as the Antichrist. The commentator also includes some of Hippolytus's interpretation of the symbolic significance of the animals, for example that the leopard symbolizes extreme wisdom and intelligence, but also violence.

Just as the Greek interpretation appeared in the lemma through the historical expansions explicitly identifying the four kingdoms, evidence for a Roman interpretation may also appear in the lemma. In Dan 7:26, which depicts the judgment of the small horn, there is a short expansion that says "the Lord ex-

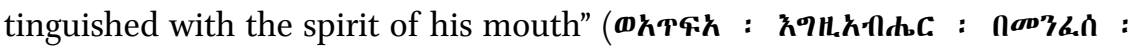
$\boldsymbol{k} \mathbf{4} \cdot \boldsymbol{v} \cdot)$. This likely draws on the description of Christ destroying the lawless one in 2 Thess $2: 8$, which was interpreted by the church as a reference to the Antichrist. This expansion is not found in the Hebrew, Greek, Syriac (at least those mss collated by the Leiden edition), or Ge'ez witnesses, meaning it may be an expansion within the Arabic version of Daniel that was used by the commentator. What is interesting here is the potential tension between this reference to 2 Thess 2:8, the expansion in Dan 7:20 that identified the little horn as Antiochus, and the commentary proper. The reference to 2 Thessalonians would connect this scene of judgment with the judgment of the Antichrist, rather than the judgment of Antiochus Epiphanes, and would fit well with a Roman interpretation of the fourth kingdom. Thus the text of Daniel in the terg'āmē preserves expansions that exhibit both the historicizing and future interpretations of Daniel 7 .

25 Hippolytus, Hippolyt Werke: Erster Band, Erster Teil: Kommentar zu Daniel, ed. Georg Nathanael Bonwetsch and Marcel Richard, GCS 7 (Berlin: Akademie, 20oo). There is an English translation in Thomas C. Schmidt and Nick Nicholas, Hippolytus of Rome: Commentary on Daniel and 'Chronicon' (Piscataway, NJ: Gorgias, 2017), and a new German translation in Katharina Bracht, Danielkommentar (Stuttgart: Hiersemann, 2016).

26 Hippolytus' treatise on the Antichrist is also extant in Ge'ez. André Caquot, "Une version ge'ez du traité d'Hippolyte de Rome sur l'Antichrist," AnE 6 (1965): 165-214. 
The sequence with Rome as the final kingdom also appears in the three extant tergwāmē to Daniel, what I am labeling TDan2 and TDan3 and TDan $5 .{ }^{27}$ For TDan2, which is attested (sometimes in dramatically different forms) in BL743 (ff.103v-119v), GG111 (ff.23r-26v), and GG112 (ff.93r-96v), the statue from Daniel 2 in its entirety represents the kingdom of Babylon. The head of gold is the kingdom of Nebuchadnezzar. The breast, hands, and arms of silver are the kingdom of Darius. The belly and hips of bronze are the kingdom of Alexander. And the legs and feet of iron and clay are the kingdom of Rome, a kingdom in which "a son did not rule on the throne of his father."

The same sequence appears in the commentary's treatment of Daniel 7. The first animal is Nebuchadnezzar, and the various elements are all understood to symbolize the episode of his exile and return recorded in Daniel 4. The animal looks like a lion because Nebuchadnezzar became like a lion. It has wings like an eagle because he resembled a bird. The wings are plucked off the animal, it stands on its feet, and it is given a human heart, all of which refer to Nebuchadnezzar's restoration. BL743 and GG112 emphasize his return to his kingdom, while GG111 emphasizes his proclamation of faith. The length of his kingdom (GG112 adds his son to the count as well) was sixty-seven years, and he came from the seed of Ham. This interest in indicating the length of the various kingdoms appears as well in Hippolytus's commentary. ${ }^{28}$

I already quoted this terg'āmē's interpretation of the bear-like animal above. GG111 does offer a different interpretation here, identifying the three bones as the kingdom of Babylon, which had three parts: Persia, the Chaldeans, and Media.

The animal like a leopard is Alexander, who was from the seed of Javan ( $\boldsymbol{\rho} \times \mathbf{2} \geqslant$, Gen 10:2), brother of Madai, who was great. The leopard-like animal has four wings in most versions of Dan 7:6, but there is a variant in some Ge'ez manuscripts that claims five wings (but still only four heads). BL 743 reads here

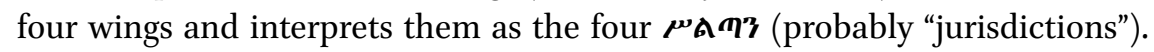
GG112 reads five wings, but interprets them also as four $\boldsymbol{\mu}_{\boldsymbol{A}} \boldsymbol{\boldsymbol { m }} \boldsymbol{\mathrm { T }}$. The four heads are the four princes who were under Alexander, whom he left at the time he killed Darius. The authority given to the animal refers to Alexander eradicating worshippers of an idol, and according to BL 743 "they" (the idol worshippers?) then worshipped God. This interesting portrayal of Alexander appears again in this manuscript's commentary to Daniel 8, where Alexander is both the goat and the horn that becomes great, throwing down and trampling the heavenly

27 TDan5 offers a special case, and not will be discussed here.

28 Hippolytus notes, for instance, that the Persians reigned 230 years (IV.3.4) or 245 years (IV.3.5). 
host and stars. Noting that Alexander was the only one of the Greek kings to worship the Lord, the commentary interprets this trampling of hosts and stars as Alexander capturing and eradicating demons, vipers, and idolaters. The scribe behind GG112 may not have been as keen about this faithful portrayal of Alexander, and, therefore, omits any reference to Alexander eradicating idolaters in Daniel 7, and says nothing about Alexander worshiping the Lord. Instead, Alexander was merely pleasing to the Lord.

Alexander rested on the twenty-first or twenty-fourth of the month of Gənbot (ninth month, May-June), and his kingdom lasted twelve years. ${ }^{29}$ There were seventeen kings of the Greeks after Alexander, and the duration of their kingdom was two-hundred and ninety-nine years. ${ }^{30}$

GG111 departs from the other witnesses in its treatment of the third animal. Rather than Alexander, this leopard-like animal is Necho, king of Egypt. It has five wings, which are the five cities of Egypt. ${ }^{31}$ The authority given to it refers to him capturing Israel and killing Jehoiachin. Here we have a fascinating example of the commentary reflecting a peculiar reading in the Ge'ez version of Daniel, which as I have already mentioned speaks of five wings rather than four.

The fourth animal is the kingdom of Rome, which is from the seed of Esau, and which is stronger than all the kings of the earth. ${ }^{32}$ The ten horns are the ten kings who reigned in Rome. ${ }^{33}$ The little horn is Antiochus, who defiled Jerusalem and "his" (God's?) holy ones. The three horns that were plucked off are the three kings who reigned in one year, whom the commentator says Ezra mentions. This is a reference to the year of four emperors and an allusion to 4 Ezra 12:22-28. GG111 departs in its treatment of the fourth animal. It also identifies it as the kingdom of Rome, quoting Luke 2:1 (the census under Augustus Caesar) as support. But it then identifies the horns, listing figures such as Herod, king of Galilee, Philip his brother, and Pilate, judge of Jerusalem. The little horn is the Antichrist and the horns he replaces are Pope Leo, Macedonius, and Arius, three heretics from a miaphysite perspective.

TDan $3{ }^{34}$ deals only with the interpretation of Nebuchadnezzar's dream from Daniel 2 and Daniel's dream-vision from Daniel 7. The exposition begins with a full quotation of Dan 2:38-45 in a form that deviates little from the mainstream

\footnotetext{
29 GG112 reads twenty-nine years.

30 GG112 reads sixteen kings. BL743 reads three-hundred and sixty-nine years.

31 Perhaps a reference to Isa 19:18. TDan5 also maintains the Ethiopic reading of five wings, interpreting them as the cities of Babylon, Persia, Media, Syria, and Greece (EMML 8971 f.57v).

32 GG112 reads "kingdoms" instead of "kings."

33 GG112 reads "until the birth of Christ."

34 BL743 ff.167r-169v; EMML 826o ff.73v-79r.
} 
Ge'ez Daniel tradition. An interpretation of Nebuchadnezzar's dream follows. After identifying the various referents of the dream, the commentary turns to Daniel 7, quoting 7:2-8 and then launching into an interpretation of the four animals. ${ }^{35}$ In its interpretation of Daniel 2, the commentary proceeds swiftly through the different portions of the statue. The head of gold represents both Nebuchadnezzar, as Daniel himself says, and the entire kingdom of Babylon, which was more exalted than all kingdoms. The shoulders and arms of silver are the kingdom(s) of Persia and Media. ${ }^{36}$ There is some ambiguity here over whether Persia and Media are considered a single kingdom or two. The singular noun for kingdom is used, but the verb is plural. Persia and Media are considered "less than gold." The belly and hips of bronze (or copper) are the kings of the Greeks, who "took the kingdom of Persia and Media." The commentator notes that Alexander killed Darius, a historical detail that appears frequently in tergwāmē to Daniel. No distinction is made between the legs and feet of the statue, with the commentator referring to the legs as consisting of iron and clay. This is the kingdom of Rome, which was "exceedingly strong." The clay represents the people whom the Romans ruled with their strength. The iron is

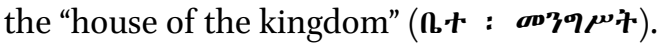

The interpretation of Daniel 7 is likewise brief. The sea from which the four animals arise is the world. The first beast, which is like a lion, is the kingdom of Babylon. Its wings, which are like those of an eagle, represents Nebuchadnezzar elevating and magnifying himself above the God of heaven. The tearing off of the wings represents "the exile of his kingdom" and his grazing with baboons

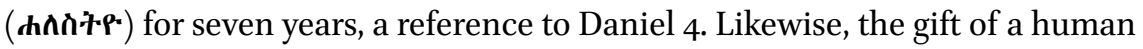
heart to the animal is Nebuchadnezzar's return and his blessing of the Lord. At this point the commentator quotes a modified version of 4 Ezra 12:15. The commentary reads:

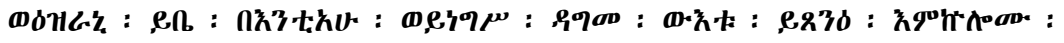
ᄎn : क्equ : (EMML 826o f.78r; BL743, ff. 168v-16gr) $)^{37}$

And Ezra also says concerning him, "And he will reign again. He will be stronger than all those before him."

$35 \quad$ BL743 omits Dan 7:3-8.

36 on the here instead of the

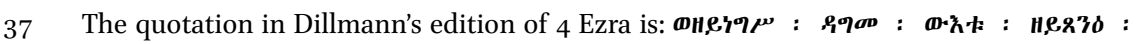

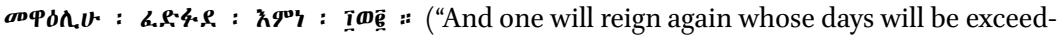
ingly stronger than the twelve"). August Dillmann, Veteris Testamenti Aethiopici Tomus Quintus, quo continentur Libri Apocryphi, Baruch, Epistola Jeremiae, Tobith, Judith, Ecclesiasticus, Sapientia, Esdrae Apocalypsis, Esdrae Graecus (Berlin, 1894). 
The commentator seems to be interpreting this as a reference to the second part of Nebuchadnezzar's reign.

The animal who looks like a bear is the kingdom of Persia, for "the people of Persia reigned after Babylon." The rib bones in the bear's mouth represent the peoples of Babylon, Persia, and Media. The third animal, the leopard, refers to the Greeks and Alexander, who took Darius's kingdom from him. The commentator points us to the goat and the ram from Daniel 8, noting that the goat represents Alexander and the ram, Darius the Mede. The commentator refers to the animal's five wings (reflecting the reading in many Ge'ez Daniel manuscripts) and four heads, identifying the four heads as representing Alexander's deathbed division of his kingdom into four parts. The fourth animal is the kingdom of Rome, with the horns representing a succession of kings. The horn that grew in their midst is the Antichrist. The emphasis on the horns being a sequence of kings rather than simultaneous rulers is interesting, and echoes the sequential emphasis of the wings in 4 Ezra's vision.

Both TDan2 and TDan3 thus agree with the Hippolytan sequence presented in TDan1, understanding the four kingdoms/kings as: (1) Babylon; (2) Media and Persia; (3) the Greeks; (4) Rome. The one deviation is GG111, which interprets the leopard-like animal as Necho, king of Egypt. It is noteworthy that TDan2 interprets the little horn as Antiochus, which is an example of the Greek interpretation interfering in a Roman interpretation of the fourth animal. This may also reflect confusion inspired by the tradition we find in Hippolytus's commentary of reading the little horn in Daniel 7 as the Antichrist, but the horn in Daniel 8 as Antiochus.

I mentioned earlier that TDanı attributes to Hippolytus the claim that the toes of the statue in Daniel 2 are the Arabs. This brings us to methods of interpreting the fourth kingdom that flourished following the rise of Islam. Just as the rise of the Roman empire gave opportunity for fresh interpretations of Daniel's visions and the four-kingdom schema, so the Arab conquests of the seventh century stimulated new theological-historiographical reflection. How were the church and synagogue to understand this transition within the larger divine plan? Already in the Umayyad period $(661-75 \mathrm{O}$ CE) there were attempts to place the Arab conquests within existing theological-historiographical models and frameworks. The four-kingdom schema was one such model. ${ }^{38}$ There

38 van Peursen, "Daniel's Four Kingdoms in the Syriac Tradition;" Harald Suermann, "The Use of Biblical Quotations in Christian Apocalyptic Writings of the Umayyad Period," in 
seems to be some variety in how exactly Arabs were inducted into this schema. Some continued to see Rome as the fourth kingdom and its collapse under Arab invaders as a temporary event or a sign that the end was near, while others, such as the Gospel of the Twelve Apostles and the seventh-century Armenian historian Sebeos, identified the Arabs as the fourth kingdom. ${ }^{39}$

The transition from legs of iron to feet of iron mixed with clay in Nebuchadnezzar's dream provided later readers with interpretive flexibility, allowing them to introduce more complexity and additional peoples or empires into the final part of the schema. The horns of the fourth beast in Daniel 7 created similar opportunity. In the primary interpretation offered by TDanı the legs and feet are understood as two phases of the Greek kingdom: first Alexander (the iron), and then his divided, warring, and intermarrying successors with varying amounts of strength (the iron mixed with clay). The Arab interpretation presented in TDanı actualizes this latent potential of a two-phased fourth kingdom, allowing the Arab Muslims to be incorporated into the Roman interpretation. The Arabs become the clay to Rome's iron, or the toes and the horns. We see an example of this interpretation in the tenth-century Karaite commentator Jephet ibn Ali, who translated Daniel and wrote a commentary in Arabic:

Then he described the fourth kingdom, which he compares to iron ... This is the kingdom of Rome, before the kingdom of Arabia arose. He makes the head the first kingdom, and the breast and arms the second kingdom, and the belly and thighs the third kingdom: and he makes the upper parts of the legs the fourth kingdom before the kingdom of Arabia ... The iron represents the Romans, and the clay the Arabs; and this is because the Romans reigned a hundred years before the Arabs; then the Arabs began to reign, but the kingdom of the Romans remained, as is witnessed in our own day. He compares the kingdom of the Arabs to clay, because they have neither power nor force like those of the Romans. ${ }^{40}$

The relevant references in the tergwāmē are in the treatment of Daniel 2:41-43 and of Daniel 7:19-28 in TDania:

The Bible in Arab Christianity, ed. David Thomas (Leiden: Brill, 2007), 69-9o; Walter Emil Kaegi, "Initial Byzantine Reactions to the Arab Conquest," CH 38 (1969): 139-49. van Peursen, "Daniel's Four Kingdoms," 202-203; Kaegi, "Initial Byzantine Reactions," $146-47$.

40 Jephet ibn Ali the Karaite, A Commentary on the Book of Daniel, trans. D. S. Margoliouth (Oxford: Clarendon, 1889), 12-13. 


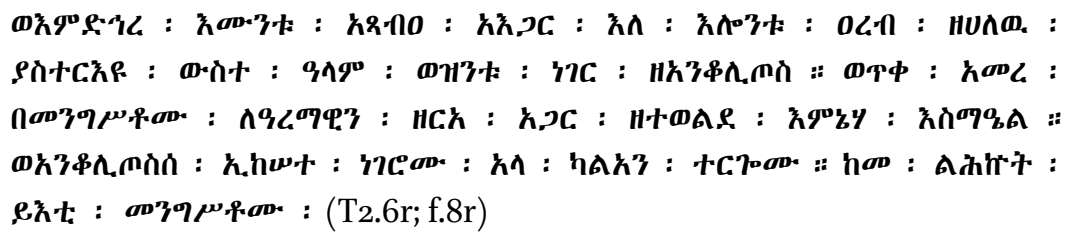

And after these were the toes, which are the Arabians who would appear in the world. This is the word of Hippolytus. And he precisely indicates the kingdom of the Arameans, the offspring of Hagar, the one who was born from her, Ishmael. Hippolytus did not reveal their language, but others have interpreted that the clay is their kingdom.

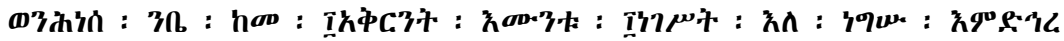

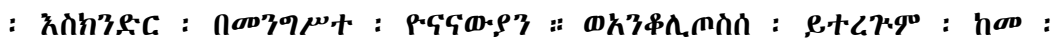

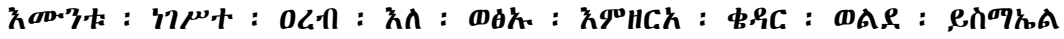
: 幺n : (T7.3h; f.1or)

And as for us, we say that the ten horns are the ten kings who reigned after Alexander in the kingdom of the Greeks. But Hippolytus comments that these are the kings of Arabia, who came from the seed of Kedar, son of Ishmael, who appear in the world until the coming of the Antichrist.

There are some questions with how we should best understand and render what is happening here, but it seems the commentator is attributing to Hippolytus the opinion that the toes of the statue are the Arabians (oc n, literally "Arabia", but used here in the sense of a people), and that the ten horns of the fourth beast are the kings of the Arabs. The commentary on Daniel 2 then clarifies who the Arabs are: they are the Aramawin, the descendants of Hagar. The commentary to Daniel 7 identifies them more specifically as the descendants of Ishmael's son Kedar. The term Aramawin has a range of possible meanings in Ge'ez and can mean non-Christian, heathen, infidel, gentile, Muslim, or Aramaic speaker. ${ }^{41}$ The commentator likely intends Muslims here, creating an equivalence between Arabs, the descendants of Hagar/Ishmael, and Muslims. Interestingly, this attribution is immediately followed by the comment that Hippolytus did not reveal their language, but others interpreted

41 As Getachew Haile notes, "Christian authors used the word Arämi when referring to nonChristians, especially the Muslims and the non-Christian Oromo" (Voices from Däbra Zämäddo [Wiesbaden: Harrassowitz, 2013], 207 n. 29). 
the clay as their kingdom. Although the Arabs were a known people at the time of Hippolytus, we do not find this interpretation in his commentary to Daniel 2-7, something our commentator admits here. In his discussion of Daniel 2, Hippolytus writes:

After them the Romans, who are the iron legs of the image, being strong as iron. Next the toes of the feet, so that in each place democracies might be shown, which are destined to come which are distributed amongst the ten toes of the image, in which the iron will be mixed with clay. $(\text { II.12.6-7 })^{42}$

In his discussion of Daniel 7 he writes:

And so we have [already] arrived [at this point and] said that it is clear that this is the fourth kingdom, from which no other greater [kingdom] or even such a kingdom [like it] has arisen on the earth, from which ten horns are about to spring forth. For it will be divided into ten kingdoms and in them another small horn shall arise, which is that of the Antichrist and he shall root out three who were before him, that is, he shall destroy the three kings of Egypt and of the Libyans and of the Ethiopians, wishing to possess for himself the whole kingdom. (IV.12.4)

For Hippolytus, writing in the early-third century $\mathrm{CE}$, the toes and horns represented coming kings and kingdoms, but other than Egypt, Libya, Ethiopia, and the Antichrist, he does not label who or what they will be. Hippolytus's interpretation is general enough, however, to allow for one to place the Arab conquest among the toes and the horns. The tergwāmè indicates that this is the case, that Hippolytus referred to something that would follow Rome, but did not explicitly identify the toes and the horns as Arabs or Muslims, a connection that later commentaries or traditions available to the commentator made explicit.

TDanıb reworks the passages in interesting ways:

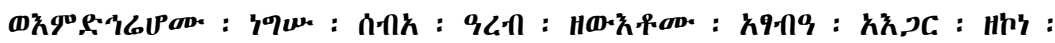

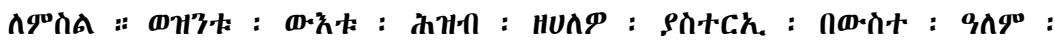

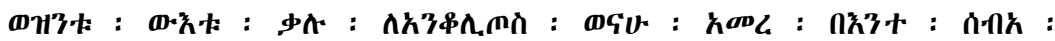

42 English translations of Hippolytus are taken from Schmidt and Nicholas, Hippolytus of Rome: Commentary on Daniel and 'Chronicon.' 


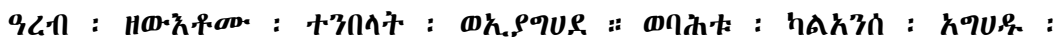

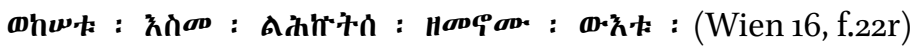

And after them the people of Arabia reigned, who were the toes of the feet which belonged to the image. And this is a nation that will appear in the world. This is the word of Hippolytus. Behold, he indicates the people of Arabia, who are the Muslims. But he did not say this openly, but only others spoke openly and revealed that the clay is their era.

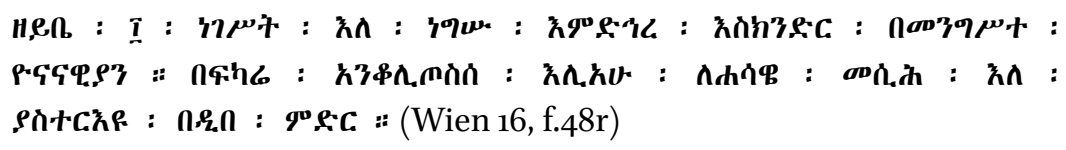

Ten kings. The ones who reigned after Alexander in the kingdom of the Greeks. In the interpretation of Hippolytus, [they are] the followers of the Antichrist who will appear upon the earth.

The scribe responsible for this recension has edited the interpretation to Daniel 2 for clarity, and made some lexical and grammatical changes. The text now specifies that the Arabs/toes were a atr-n (nation) that has appeared in the world. Rather than speaking of the Aramawin, it identifies the "people of Arabia" with +3n^t, a clear designation for Muslims. Rather than discussing their genealogy (the descendants of Ishmael, son of Hagar), their religious identity is emphasized. Although the word Arab seems to be attributed to Hippolytus, this scribe makes it even clearer that Hippolytus himself did not clearly say this, but that others have made it clear that the clay refers to the time of the Arabs/Muslims. In the discussion of the ten horns the scribe has removed any explicit reference to the Arabs, saying that for Hippolytus the ten kings are the followers of the Antichrist who will appear on the earth.

Our commentator was aware of the widespread traditions that incorporated the Arabs into the final phase of the statue in Daniel 2 and the fourth animal in Daniel 7, and may offer evidence that some were interpreting Hippolytus in this way.

The tergwāmē to Daniel collect three major interpretive traditions of Daniel 2 and 7. The commentator from TDanı opts for the position that is attested primarily in Syriac circles, that the legs and feet of the statue and the fourth 
animal with its ten horns refer to the kingdom of Alexander and his successors, culminating in the wickedness of Antiochus Epiphanes. Through this commentary's engagement with Hippolytus of Rome and in TDan2 and TDan3 we find the collapsing of the Medes and Persians into a single kingdom and the identification of the fourth kingdom as Rome (with one witness claiming the third beast as Pharaoh Necho). And finally, we encounter the Byzantine incorporation of the Arab conquest and Muslims into the final stages of Daniel's schema in TDanı's reception of Hippolytus.

Each of these methods of interpretation were strongly attested in the ancient and medieval worlds, and each of them continues to have advocates today. The first interpretation dominates in historical-critical scholarship, which, like our commentator, sees the struggles of Jews in the second century вСЕ as the culmination of the dream-visions in Daniel. The second interpretation, which emphasizes Rome, Christ, and Antichrist, may be considered a dominant reading in the history of Christian interpretation, and continues to be advocated by many modern Christians. ${ }^{43}$ The third interpretation, which finds Arabs and Muslims in Daniel's visions, was widespread following the rise of Islam, and is also experiencing a contemporary revival among some Christian apocalypticists amidst rampant Islamophobia. ${ }^{44}$ Multiple understandings of these visions have existed and co-existed for the last two millennia, and in the Ethiopian tergwāmē tradition we find them co-existing not only amongst different commentary texts, but within a single commentary.

How does TDanı handle its inheritance of conflicting interpretative traditions? Jerome's commentary to Daniel, which interacts with Porphyry's interpretation of Daniel, offers a charged, polemical treatment of different approaches to deciphering the referents of Daniel's visions. This is not the case in this tergwāmè. It presents itself as a collection of tradition, drawing on previous, largely unnamed commentators in its work. ${ }^{45}$ It is capable of polemic,

43 One example is the popular early-twentieth century Scofield Reference Bible (ed. C. I. Scofield [New York: Oxford University Press, 1917]), which reflected and influenced the development of dispensationalist fundamentalism. This Bible includes headings for each of the four animals in Daniel 7, which read: "(1) The world-empire of Nebuchadnezzar ... (2) The world-empire of Media-Persia ... (3) The world-empire of Greece under Alexander ... (4) The Roman world-empire." This four-kingdom scheme has often led to an expectation of a restored Roman empire before the eschaton. This led many fundamentalists to speculate that Benito Mussolini, who sought to restore the Roman Empire, was the Antichrist (Matthew Avery Sutton, American Apocalypse: A History of Modern Evangelicalism [Cambridge, MA: Belknap, 2017], 213-17).

44 Cf. Joel Richardson, The Islamic Antichrist (Washington, DC: WND Books, 2015).

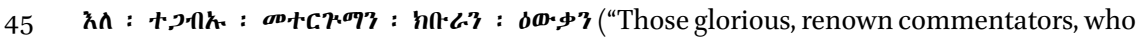
have been collected"; T12.3a, f.78v). 
but often offers multiple unattributed interpretations without any attempt to weigh or value them. In some cases interpretations drawn from Hippolytus are seamlessly incorporated without citation or comment, indicating a generally positive appraisal of his work and his usefulness as a source for understanding the text of Daniel. He is titled a saint, martyr, and bishop, and in some cases his agreement with the perspective of the commentary is emphasized (even if he is not really in agreement). Yet in its lengthy citations and paraphrases of Hippolytus, the commentator repeatedly draws attention to where the saint diverges from the perspective offered by the terg'āmē, in one case making it clear that the interpreting angel within Daniel 7 agrees with the commentary against Hippolytus (see above).

Near the end of the tergwāmē the commentator attempts to rationalize the incorporation of Hippolytus's work. There they note that their Antiochus Epiphanes-centered interpretation is in agreement with the "honorable and famous" commentators who were drawn upon as sources. However, Saint Hippolytus, bishop of Rome and martyr, believes Daniel is referring not to Antiochus Epiphanes, but rather to the Antichrist. They then write: "Even though [Hippolytus] does not agree with all of the commentators in this (matter), it is not appropriate to discard his commentary." They claim that Hippolytus interprets the word of the prophets with many interpretations, because this word is "hidden and deep," and what he interprets from it will be a second symbolism. The tergwāmē continues to note that commentators adopt non-Christological readings of some prophecies, but many of the apostles interpret those same prophecies with reference to Christ. Yet their interpretations are not discarded. Likewise, although the text refers to Antiochus, Antiochus's deeds resemble what will happen with the Antichrist. The commentator says they are making this point, so that no one will "disgrace this saint and call him a fool." The commentator thus attempts to ultimately defend Hippolytus's interpretations and integrate them with their own by reading them as interpretations of the figurative meaning of the text. The need to defend this prestigious saint from the accusation of foolishness shows that the commentator is writing in a milieu where the interpretation of the fourth kingdom as the Greeks was accepted as exegetical common sense. ${ }^{46}$ This commentator, however, makes room for the alternative insights of an ancient bishop and martyr.

46 This was the case in Syriac Christian circles: "Although Van der Kooij is right that the Greek interpretation differs from the majority view attested in Christian sources, we should be aware that in the Syriac tradition the Greek interpretation is predominant" (van Peursen, “Daniel's Four Kingdoms in the Syriac Tradition," 196). 


\section{Bibliography}

An, Keon-Sang. An Ethiopian Reading of the Bible: Biblical Interpretation of the Ethiopian Orthodox Tewahido Church. Eugene, OR: Pickwick, 2015.

Avery Sutton, Matthew. American Apocalypse: A History of Modern Evangelicalism. Cambridge, MA: Belknap, 2017.

Bracht, Katharina. Danielkommentar. Stuttgart: Hiersemann, 2016.

Butts, Aaron Michael. "Embellished with Gold: The Ethiopic Reception of Syriac Biblical Exegesis." OrChr 97 (2013/2014): 137-159.

Caquot, André. “Une version ge`ez du traité d'Hippolyte de Rome sur l'Antichrist.” AnE $6(1965): 165^{-214}$.

Catalogue of Manuscripts Microfilmed by the UNESCO Mobile Microfilm Unit in Addis Ababa and Gojjam Province. Addis Ababa: Ministry of Education and Fine Arts, Department of Fine Arts and Culture, 1970.

Cowley, Roger W. The Traditional Interpretation of the Apocalypse of St. John in the Ethiopian Orthodox Church. Cambridge: Cambridge University Press, 1983.

Cowley, Roger W. "A Ge'ez Document Reporting Controversy concerning the Bible Commentaries of Ibn at-Tayib." RSE 30 (1987): $5^{-13}$.

Cowley, Roger W. Ethiopian Biblical Interpretation: A Study in Exegetical Tradition and Hermeneutics. Cambridge: Cambridge University Press, 1988.

Dillmann, August. Veteris Testamenti Aethiopici Tomus Quintus, quo continentur Libri Apocryphi, Baruch, Epistola Jeremiae, Tobith, Judith, Ecclesiasticus, Sapientia, Esdrae Apocalypsis, Esdrae Graecus. Berlin, 1894.

Fishbane, Michael. Biblical Interpretation in Ancient Israel. Oxford: Clarendon, 1985.

Fuhs, Hans Ferdinand. Die äthiopische Übersetzung des Propheten Micha. Bonn: Hanstein, 1968.

Fuhs, Hans Ferdinand. Die äthiopische Übersetzung des Propheten Hosea. Bonn: Hanstein, 1971.

Garcia, Miguel Angel. Ethiopian Biblical Commentaries on the Prophet Micah. AeF 52. Wiesbaden: Harrassowitz, 1999.

Getachew Haile. Voices from Däbra Zämäddo. Wiesbaden: Harrassowitz, 2013.

Hippolytus. Hippolyt Werke: Erster Band, Erster Teil: Kommentar zu Daniel. Edited by Georg Nathanael Bonwetsch and Marcel Richard. GCS 7. Berlin: Akademie, 2000.

Hjälm, Miriam Lindgren. Christian Arabic Versions of Daniel: A Comparative Study of Early MSS and Translation Techniques in MSS Sinai Ar. 1 and 2. Leiden: Brill, 2016.

Jenner, Konrad D. "Syriac Daniel." Pages 6o8-638 in vol. 2 of The Book of Daniel: Composition and Reception. Edited by John J. Collins and Peter W. Flint with the assistance of Cameron VanEpps. VTSup 83. FIOTL 2. Leiden: Brill, 2001.

Jephet ibn Ali the Karaite. A Commentary on the Book of Daniel. Translated by D. S. Margoliouth. Oxford: Clarendon, 1889. 
Kaegi, Walter Emil. "Initial Byzantine Reactions to the Arab Conquest." cH 38 (1969): 139-49.

Kooij, Arie van der. "The Four Kingdoms in Peshitta Daniel 7 in the Light of the Early History of Interpretation." Pages 123-129 in The Peshitta: Its Use in Literature and Liturgy. Edited by Bas Ter Haar Romeny. Leiden: Brill, 2006.

Löfgren, Oscar. Die äthiopische Übersetzung des Propheten Daniel. Paris: Geuthner, 1927. Mordini, Antonio. "Il convento di Gunde Gundiè." RSE 12 (1953): 29-7o.

Newsom, Carol A. with Brennan W. Breed. Daniel: A Commentary. ot L. Louisville: Westminster John Knox, 2014.

Peursen, Wido van. "Daniel's Four Kingdoms in the Syriac Tradition." Pages 189-207 in Tradition and Innovation in Biblical Interpretation: Studies Presented to Professor Eep Talstra on the Occasion of his Sixty-Fifth Birthday. Edited by W. Th. van Peursen and J. W. Dyk. Leiden: Brill, 2011.

Rhodokanakis, Nikolaus. Die äthiopischen Handschriften der K. K. Hofbibliothek zu Wien. Wien: Hölder, 1906.

Richardson, Joel. The Islamic Antichrist. Washington, DC: WND Books, 2015.

Rowley, H. H. Darius the Mede and the Four World Empires in the Book of Daniel: A Historical Study of Contemporary Theories. Cardiff: University of Wales Press, 1964.

Sanders, J. C. J. Commentaire sur la Genèse. csco 274-275. Leuven: Peeters, 1967.

Schmidt, Thomas C. and Nick Nicholas. Hippolytus of Rome: Commentary on Daniel and 'Chronicon.' Piscataway, NJ: Gorgias, 2017.

Scofield, C. I., ed. Scofield Reference Bible. New York: Oxford University Press, 1917.

Stoffregen-Pedersen, Kirsten. Traditional Ethiopian Exegesis of the Book of Psalms. AeF 36. Wiesbaden: Harrassowitz, 1995.

Suermann, Harald. "The Use of Biblical Quotations in Christian Apocalyptic Writings of the Umayyad Period." Pages 69-9o in The Bible in Arab Christianity. Edited by David Thomas. Leiden: Brill, 2007.

Weldetensae Andeberhan. Commentari Etiopici sul Libro del Profeta Osea. AeF 40. Wiesbaden: Harrassowitz, 1994. 